\title{
A FORMAÇÃO, RESISTÊNCIA E IDENTIDADE DA COMUNIDADE QUILOMBOLA DOS CANDENDÊS
}

Renato da Silva Melo ${ }^{1}$

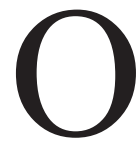

tema deste trabalho é o Quilombo dos Candendês, comunidade formada por negros alforriados, fugidos e de heranças legadas pelo fim da escravidão. Esta pesquisa evidenciou existir na região de Barbacena uma organização com identidade forjada na luta pela terra para a sobrevivência. Existem três diferentes discursos sobre a origem do Quilombo dos Candendês. Uma hipótese é que essa terra pertencia ao coronel Abel Moreira Campos, que a doou a Antônio Lourenço, o Candendê. O segundo relato contraria a primeira versão, ao afirmar que a terra pertencia inicialmente a Antônio Lourenço, e que o coronel Abel a teria comprado. Já um outro relato menciona ainda que os primeiros Candendês seriam um conjunto de várias famílias de ex-escravos que foram viver neste local após a abolição. A terra da região do Ponto Chique do Martelo foi denominada pelos órgãos públicos como Sítio dos Candendês, ou crioulos.

Temos nesta história um personagem intrigante: o Candendê, negro liberto e cercado de elementos místicos. A Comunidade Quilombola dos Candendês está situada na localidade do Ponto Chique do Martelo, um

1 Doutor em História pela Universidade Federal de Minas Gerais (UFMG). renatosim@yahoo. com.br 
dos treze distritos do município de Barbacena, Minas Gerais. Atualmente residem no círculo associativo da comunidade cerca de 75 famílias, constituindo aproximadamente 375 pessoas, que vivem basicamente do sistema de agricultura de subsistência e também da produção de leite. $\mathrm{Na}$ comunidade há apenas uma escola de ensino infantil e fundamental I, um bar, um restaurante, uma igreja católica, um templo evangélico e dois terreiros de umbanda. Não há ruas com identificação nem iluminação noturna, muito menos água encanada e tratada. O distrito onde está localizada a comunidade fica a 24 quilômetros de Barbacena.

A Comunidade Quilombola dos Candendês tem grande importância para a memória coletiva dos moradores, para o povo barbacenense e para os brasileiros, de forma mais ampla, uma vez que a memória pode significar não apenas uma conquista, mas também a manutenção de seu domínio sobre o poder, razão da luta pela dominação da recordação e da tradição. Le Goff afirma que tornar-se senhores da memória e do esquecimento é uma das grandes preocupações das classes que dominaram as sociedades históricas. ${ }^{2}$ Talvez, por isso, não temos acesso à história contada pelo povo e, sim, a uma história de nossa cidade e nossa região contada por esses senhores. É em função das necessidades do hoje que inquirimos o ontem, já que "a memória é um elemento essencial da identidade social e coletiva". ${ }^{3} \mathrm{E}$ a escuta das histórias contadas ou narradas é, para nós, um gênero que, entre outras tantas funções, é capaz de resgatar e manter nossa memória.

O que busco é a reconstituição de uma história interrompida, "silenciada", vivenciada cotidianamente pela Comunidade Quilombola dos Candendês, já que os silêncios da história são reveladores dos mecanismos de manipulação da memória coletiva. Para que possamos entender o nosso locus histórico atual e o locus histórico desta comunidade, precisamos falar do que calamos, evidenciar o oculto, analisar questões que nos perturbam ainda hoje e que são potencializadas pelas dificuldades socioeconômicas e culturais experienciadas por esta comunidade. Para a compreensão dos Candendês, seguirei a linha teórica esboçada por

2 Jacques Le Goff, História e memória, tradução de Bernardo Leitão, Campinas: Unicamp, 2003.

3 Le Goff, História e memória, p. 477. 
Flávio Gomes, quando percebe os quilombos como espaço de homens que forçam suas relações com o mundo ao seu redor. ${ }^{4}$ Gomes combate a visão antiga, ainda presente em uma parte da historiografia, de que os quilombos eram agrupamentos marginais ao mundo da escravidão.

Segundo o autor, os quilombos não eram territórios isolados. Ao contrário, ele mostra que em alguns quilombos fluminenses do século XIX e em outros lugares e épocas anteriores, estabeleciam-se relações contínuas entre quilombolas e cativos, relações econômicas, culturais e familiais. O quilombola era um membro da comunidade escrava que, frequentemente, circulava entre a escravidão e a liberdade, ajudando a coletividade dos cativos a redefinir, perante os senhores, novos espaços de barganha. ${ }^{5}$ Esse é o caso da Comunidade dos Candendês, cujos membros trocaram influências sociais e culturais com seus vizinhos, forjaram alianças para sobreviver quando o monopólio da violência não era apenas estatal. A nova historiografia da escravidão concebe os escravos enquanto sujeitos complexos, que formataram a sua própria história em diversas direções e agiram com sentidos próprios, mas multifacetados. Os indivíduos e as coletividades tornam-se sujeitos de suas histórias. A existência mediana, a ação intermediária, os sutis avanços e recuos, as pequenas, mas importantes conquistas, os gestos modestos, porém, profundos, têm importância na configuração identitária dos sujeitos históricos. Procuro, neste artigo, estabelecer a possibilidade de reconhecimento da Comunidade Quilombola dos Candendês, construindo um perfil que implique na percepção de suas experiências e trajetórias comuns, e a apreensão de suas formas de representação da identidade coletiva. É meu interesse, então, reconstruir os aspectos da história da região perscrutando, ouvindo e pesquisando a história e a memória dos silenciados da Comunidade Quilombola dos Candendês.

O termo "remanescente" funciona como uma classificação dos habitantes de terras de pretos que pode sugerir sobras, resíduos ou restos, aos quais se reconhece profundas perdas culturais, mas que não nega os seus direitos ao estatuto legal. O reconhecimento como remanescente,

4 Flávio dos Santos Gomes, Histórias de quilombolas: mocambos e comunidades de senzalas no Rio de Janeiro: século XIX, Rio de Janeiro: Arquivo Nacional, 1995.

5 Gomes, Histórias de quilombolas, 1995. 
que para muitas comunidades tem se mostrado um caminho importante de garantir suas terras e sua voz política, antes de ser uma ação de naturalização de identificação do que é dado, funciona no sentido de as obrigar a compreender as transformações operadas na ideologia dominante para que possam aceitar e se adaptar a esses novos papéis. Isso pode significar fazer opções a partir do que poderíamos pensar enquanto uma "plasticidade identitária", que se abre a outras possibilidades. ${ }^{6}$

\section{Justiça e escravidão}

A Comunidade Quilombola dos Candendês localiza-se na cidade de Barbacena, antiga Vila da Estrada Real, ficando a meio caminho do município de Ouro Preto e da velha capital Rio de Janeiro. Com a notícia da descoberta de ouro na região das Minas Gerais, houve um fluxo contínuo de pessoas vindas das regiões paulistas e do reino de Portugal. Havia aquela esperança de enriquecimento rápido, pois o ouro de nossa região era de aluvião, portanto bastante fácil de explorar. Chegava-se a Minas Gerais vindo do Rio de Janeiro ou de São Paulo pelo Caminho Geral do Sertão, mais tarde conhecido como Caminho Velho. Devido também às riquezas auferidas pelos diamantes, na região de Diamantina, foram explorados os caminhos que ligavam ao sul da Bahia. A maioria desses caminhos foi feito pelos indígenas, logo em seguida explorados e ampliados pelos bandeirantes paulistas. Com o uso constante pelos sertanistas, para procurarem os gentios da terra, os caminhos das Minas passaram a ser regularmente frequentados a partir de 1696.

Esses caminhos tornaram-se importantes, por trazer às regiões mineradoras pessoas que queriam enriquecer também com a posse de terra. Logo no início do século XVIII, a concentração de terras já era uma realidade, transformando os primeiros proprietários em Senhores do Caminho. Para o estabelecimento desses primeiros proprietários houve a necessidade de uma quantidade maior de mão de obra. O braço escravo, já tendo demonstrado sua energia e vigor no Nordeste, agora recebia novas demandas: o trabalho nas minas e nas lavouras, embora tenha indígenas e quilombolas", Mana, v. 3, n. 2 (1997), pp. 7-38. 
sofrido algumas resistências das autoridades portuguesas. ${ }^{7}$ Os escravos ajudaram tanto no planejamento da exploração das minas quanto em sua operacionalidade e rendimentos, pois já detinham conhecimentos técnicos adquiridos nas terras africanas. Na província de Minas Gerais, com destaque para a Comarca do Rio das Mortes, a economia foi reestruturada com a produção mercantil de alimentos. ${ }^{8} \mathrm{Na}$ região de Barbacena, que fazia parte daquela Comarca, a força escrava foi utilizada sobretudo na agropecuária, devido à necessidade de abastecimento tanto da área mineradora quanto da população crescente da nova capital da colônia, São Sebastião do Rio de Janeiro.

A região de Barbacena e o sítio dos Candendês - confins agrário, pecuarista e, em menor escala, produtora de têxteis -, caracterizava-se pela presença de pequenos plantéis de escravos, adquiridos no tráfico interprovincial urbano e nas zonas de atividades agrícolas não exportadoras. ${ }^{9}$ Esse fato consubstanciava-se na aproximação entre os senhores e seus cativos, o que não descarta a presença significativa de conflitos que margeiam as relações, nos quais a submissão é o fator preponderante para manter a ordem.

No período colonial, com destaque para a província mineira, a Igreja Católica trabalhava de maneira importante no controle dos escravos, já que procurava integrá-los à vida da comunidade. A Igreja, ao interferir nas relações entre senhores e escravos, estava ajudando os últi-

7 Francisco Vidal Luna e Iraci Del Nero Costa, Minas colonial: economia e sociedade, São Paulo: FIPE/Pioneira, 1982, pp. 6-7.

8 Em 1978, Maria Yedda Linhares polemizou a respeito do quadro mofino surgido com o esgotamento das lavras auríferas. Algumas perguntas lançadas naquele momento se conservam atuais. Interrogando-nos sobre a "visão indiferenciada de uma decadência inexorável e monolítica, sem atentar para as infinitas diversificações locais", a autora indicou alguns rumos para a pesquisa do passado mineiro. Era preciso saber que grupos da estrutura social e produtiva foram atingidos, qual o grau de impacto sofrido pelas diferentes regiões de Minas Gerais. Cf. Maria Yedda Leite Linhares, "O Brasil no século XVIII e a Idade do Ouro: a propósito da problemática da decadência", in Seminário sobre a cultura mineira no periodo colonial (Belo Horizonte: Conselho Estadual de Cultura de Minas Gerais, 1979), p. 168. A ideia de atrofia econômica veio a ser alterada definitivamente pelos trabalhos de Roberto Borges Martins, Robert Slenes, Douglas Libby, entre outros. Uma avaliação das discussões historiográficas de Minas Gerais pode ser encontrada em Douglas Cole Libby, "Historiografia e a formação social escravista mineira", Revista Acervo, v. 3, n. 1 (1988), pp. 7-20.

9 Robert Slenes, The Demografphy and Economics of Brazilian Slavery, Palo Alto: Stanford University Press, 1976. 
mos, ao mesmo tempo que levava em frente sua missão evangelizadora. No entanto, ao obter mais proteção e direitos, os cativos "reconheciam implicitamente o sistema que os mantinha em cativeiro". ${ }^{10}$ Nas Minas setecentistas, o Conde de Assumar via o processo de evangelização como um respeitável veículo, tanto para salvar a alma quanto como um mecanismo de aculturação dos valores europeus e de controle político. Ao mesmo tempo que os escravos aprendiam os valores religiosos, assimilavam o poder do Estado, o reconhecendo enquanto detentor do monopólio da violência. ${ }^{11}$

Tanto no distrito Padre Brito, vinculado à Barbacena, quanto na paragem do Ponto Chique do Martelo, houve um fluxo contínuo de escravos vindo do Rio de Janeiro e do tráfico interprovincial, no século XIX. De fato, em 1872, as maiores populações de escravos estavam em Minas Gerais, com um total de 208.103 cativos, seguido pelo Rio de Janeiro, com 207.709. O terceiro estado era o da Bahia, perfazendo um total de 103.095 cativos. São Paulo, por ingressar mais tarde na produção do café e com a entrada maciça de imigrantes, tinha um quadro menor de mão de obra escrava, mesmo assim, seu contingente era de 82.843 indivíduos. Próximo de 1833, o Termo de Barbacena possuía uma população em torno de 2.743 indivíduos. Desse total, 1.762 eram pessoas livres, 979 escravos e dois forros. ${ }^{12}$ Por volta de 1872, a população da cidade já era de aproximadamente 19.503 indivíduos, divididos em 14.513 livres e 4.990 escravos. No entanto, a grande maioria dessas pessoas livres era composta de não brancos, ou seja, pessoas categorizadas como negros, pardos, caboclos e que se somados aos escravos, totalizavam 10.348 pessoas. $^{13}$

É desse universo de não brancos, de escravos e ex-escravos que constituirá o Quilombo dos Candendês. Ser quilombola era um item do

10 Donald Ramos, "O quilombo e o sistema escravista em Minas Gerais do século XVIII", in João José Reis e Flávio dos Santos Gomes (orgs.), Liberdade por um fio: história dos quilombos no Brasil (São Paulo: Companhia das Letras, 2011), p. 170.

11 Ramos, “O quilombo", p. 170.

12 Listas nominativas de 1831-1832: distrito do Termo de Barbacena. Arquivo Público Mineiro.

13 Instituto Brasileiro de Geografia e Estatística, Recenseamento do Brasil em 1872, Rio de Janeiro, IBGE, 1872, pp. 700-702. <https://biblioteca.ibge.gov.br/biblioteca-catalogo $\mathrm{id}=225477 \&$ view $=$ detalhes $>$, acessado em 15/10/2019. 
"currículo" de escravo, o que forçou muitos senhores a amenizar as brutalidades em determinados contextos sociais e políticos. Na formação de quilombos estava a luta contra a intransigência de senhores que desrespeitavam certos ganhos que, a partir da estruturação do sistema jurídico no país, os escravos começaram a considerar como direitos. Dessa forma, muda-se seu reconhecimento, passando de indivíduos penalizáveis por crimes, ou seja, imputáveis, mas sem direitos, a sujeito de direitos, ainda que limitado pelo sistema escravista. O universo de relações entre os quilombolas e outros grupos sociais ia além da senzala, comercializando com os taberneiros e trabalhando para fazendeiros e pequenos lavradores.

$\mathrm{Na}$ estruturação do Estado brasileiro, no século XIX, lançou-se mão da instituição da justiça para tornar legal o consenso forçado entre as elites. A elite mineira foi pensada em sua peculiaridade, constituindo-se por representantes dos proprietários escravistas. Os integrantes dessa elite se destacavam por sua capacidade intelectual e organizativa, e por estabelecerem uma relação orgânica com a propriedade, mediatizada pelas afinidades que estabeleciam com os outros grupos sociais, bem como pela influência do pensamento liberal. O amálgama de formação diversa, imerso na dinâmica social mineira e interagindo com a prática política, é que deu os fundamentos da unidade da elite provincial mineira. ${ }^{14}$ Neste momento, o ordenamento jurídico veio respaldar os interesses políticos em voga. Isso porque o governante precisava do direito para dar legitimidade à suas ações, e oferecia ao governo aquilo que Carl Schmitt chamava de politischer Mehrwerth (mais-valia política). ${ }^{15}$ O Estado, nesse período, para ser reconhecido como detentor do controle da ordem e da administração dos conflitos, teve que abrir margem para negociação. ${ }^{16}$ Criava-se, assim, uma falsa sensação de segurança para os subalternos, ou pelos menos deveria ter essa a intenção quando se inscreveu as constituições no século XIX. O sistema jurídico

14 Wlamir Silva, Liberais e povo: a construção da hegemonia liberal na Província de Minas Gerais (1830-1834), São Paulo: Hucitec, 2009, p. 126.

15 Carl Schmitt, "Die legale weltrevolution. polítischer mehrwert als prämie auf juristische legalität und superlegalität”, Der Staat, v. 17, n. 3 (1978), pp. 321-339.

16 Ivan de Andrade Vellasco, As seduções da ordem: Violência, criminalidade e administração da justiça, Minas Gerais, século XIX, São Paulo: Anpocs, Bauru: Edusc, 2004, p. 21. 
assegurou a mais-valia política aos governantes ordinários, mas deixou de legitimá-la para as classes subalternas.

O Código Criminal de 1830 assegurava que, diante da docilidade do povo brasileiro, sua ignorância, inclusive escolar, deveria ser mantida a pena de morte. Ela teria um fim corretivo. Nessa letra, fica patente o perigo ou o medo que as elites estavam vivendo por causa da grande resistência ao escravismo. Por isso, a pena capital deveria ser em praça pública, na forca, conforme o artigo 38 do Código. ${ }^{17}$ É comum observarmos, em algumas imagens do período imperial, vários negros em trabalhos públicos obrigatórios com calceta no pé e corrente de ferro, aludindo serem réus de pena de galés. Havia também a pena de multa, com a introdução da ideia do "dia-multa", muito utilizado hoje em dia. Aqueles que não conseguiam pagar a multa, deveriam pagar com traba1ho. ${ }^{18}$ A Constituição de 1824 garantia que não haveria penas como os açoites, a tortura, a marca a ferro quente (art. 179, inciso 19). O inciso 13, da Constituição Outorgada em 1824, afirmava que a lei deveria ser igual para todos, menos para os escravos, que eram considerados coisas, por um lado, e pessoas, no caso de delitos, por outro. No entanto, o Código afirmava:

Art. 60. Se o réo for escravo, e incorrer em pena que não seja a capital ou de galés será condenado a de açoutes, e, depois de os soffrer, será entregue a seu senhor, que se obrigará a trazel-o com um ferro pelo tempo e maneira que o juiz o designar. O número de açoutes será fixado na sentença; e o escravo não poderá levar por dia mais de cincoenta. (grifos nossos) ${ }^{19}$

O Código de Processo Criminal, de 29 de novembro de 1832 , deu nova fisionomia aos municípios, pois foram habilitados a exercer atribuições judiciárias e policiais, ${ }^{20} \mathrm{o}$ que concedeu força e aumento de poder aos coronéis e elites políticas locais. Esse monopólio da violên-

17 Brasil, Código criminal, Rio de Janeiro: Livraria Popular A. A. da Cruz Coutinho, 1877, art. 38, p. 85.

18 Brasil, Código, art. 57, p. 102.

19 Brasil, Código, art. 60, p. 109. Grifo nosso.

20 Brasil, Código, art. 106, p. 174. 
cia foi usado principalmente contra os povos subalternos e quilombolas. Alguns senhores escravocratas, revoltados com o aumento da criminalidade mancípia e a comutação das penas de morte em sentenças de galês perpétuas, tomavam os escravos das cadeias ou os sequestravam quando estavam sendo levados para a prisão, com o objetivo de fazer justiça com as próprias mãos. ${ }^{21}$ Esse foi o caso dos escravos que assassinaram o senhor Antônio Gabriel Monteiro de Barros e dos que roubaram o Barão de Bertioga na região de Juiz de Fora. No caso de Monteiro de Barros, os escravos "morreram" no desenrolar do processo, e dos três acusados de roubo do Barão, dois foram encontrados mortos, pois tinham "suicidados", e um terceiro foi "envenenado pelos comparsas". ${ }^{22}$ Manoel Barbosa Lage mandou vender um escravo que havia se envolvido em conflito e o conde Prados optou por aplicar uma punição interna, ou seja, mandou para o eito, um cativo especializado, colocou-o no tronco e pôs ferro em seu pescoço por crime passional. ${ }^{23}$ Podemos perceber que o Estado não sobrepujou os domínios dos senhores, pois eles tinham a decisão final sobre o governo de suas casas e de seus homens. No interior de sua propriedade, o fazendeiro exercia uma justiça penal particular. Mesmo quando entregavam seus cativos à justiça do Estado, para ser julgado de acordo com o ordenamento jurídico, os fazendeiros não perdiam a oportunidade de aplicar o seu próprio código de justiça. Como demonstrou João Luiz Pinaud, a justiça era aplicada conforme a condição dos envolvidos. ${ }^{24}$ Diante dessa severidade e do monopólio privado da violência, os quilombos eram espaços societários de resistência.

Recentemente, as discussões em torno do reconhecimento das terras de quilombolas, amparadas pelo artigo 68 do Ato das Disposições Constitucionais Transitórias (ADCT), da Constituição Brasileira de

21 Gomes, Histórias de quilombolas, p. 329.

22 Elione Silva Guimarães, Múltiplos viveres de afrodescendentes na escravidão e no pós-emancipação: familia, trabalho, terra e conflito (Juiz de Fora-MG, 1828-1928), São Paulo: Annablume, Juiz de Fora: Funalfa Edições, 2006, p. 85-86.

23 Elione Silva Guimarães, "Amores ilícitos: os crimes passionais na comunidade escrava: Juiz de Fora, Minas Gerais, segunda metade do século XIX”, Varia História, v. 17, n. 25 (2001), pp. 165-193.

24 João Luiz Pinaud, "Senhor, direito e justiça", in Insurreição negra e justiça (Rio de Janeiro: Expressão e Cultura/Ordem dos Advogados do Brasil-RJ, 1987), pp. 41-112. 
$1988,{ }^{25}$ contribuíram para promover o interesse de pesquisadores pelo acesso dos povos libertados à terra, antigo meio de produção. Segundo o texto da Carta Magna, é preciso que os sujeitos históricos presumíveis existam no presente e tenham como condição básica o fato de ocupar uma terra, em seu nome titulada. Desta forma, qualquer invocação do passado deve corresponder a uma forma atual de existência capaz de realizar-se a partir de outros sistemas de relações que marcam seu lugar num universo social determinado. Esse aspecto presencial tem levado os antropólogos a seguir o princípio básico de fazer o "reconhecimento teórico e encontrar o lugar conceitual do passado no presente". ${ }^{26} \mathrm{O}$ artigo 68 do ADCT é um dispositivo mais voltado para o passado e do que teria sobrevivido sob a designação de remanescente quilombola. Nessa moldura de passadismo, havia a dubiedade da ideia de monumentalidade e sítio arqueológico que dominara o universo ideológico dos legisladores. Por causa dessa compreensão, iniciou-se a discussão sobre qual conceito de quilombo estava em jogo, pois as definições com pretensão classificatória são por princípio arbitrárias e colocam na ordem do dia os interesses opostos. Com as mobilizações camponesas após 1988, o fator étnico foi publicizado e tornado componente dos critérios político-organizativos. Os conflitos em torno do conceito de quilombo e dos procedimentos operacionais revelaram o grau de organização dos grupos interessados que recusaram o caráter restritivo do único instrumento legal produzido após a Lei Áurea, de 1888. ${ }^{27}$ A conceituação jurídica de comunidades quilombolas, segundo o Decreto n. 4.887 de 20 de novembro de 2003, em seu art. $2^{\circ}$, afirma que elas se constituem de grupos étnico-raciais, conforme "critérios de autoatribuição, com trajetória histórica própria, dotados de relações territoriais específicas, com presunção de ancestralidade negra relacionada com a resistência à opressão histórica sofrida." ${ }^{28}$

25 Brasil, Constituição da República Federativa do Brasil, Brasília: Edições da Câmara, 1988.

26 Sahlins apud Eliane Cantarino O'Dwyer, "Introdução", in Quilombos: identidades étnicas e territorialidade (Rio de Janeiro: EDFGV, 2002), p. 14.

27 Alfredo Wagner Berno de Almeida, "Os quilombos e as novas etnias", in Eliane Cantarino O’Dwyer (org.), Quilombos: identidades étnicas e territorialidade (Rio de Janeiro: EDFGV, 2002), pp. 46-47.

28 Cf. $<$ http://www.planalto.gov.br/ccivil_03/decreto/2003/d4887.htm>, acessado em 17/12/217. 
$\mathrm{Na}$ África, os "Kilombos" eram acampamentos que se deslocavam de acordo com as necessidades de combate e com uma rigorosa hierarquia e disciplina militar. Sob o comando da rainha Jinga, os quilombos passaram a compor uma frente de resistência contra os inimigos. No Brasil, os quilombos caracterizaram-se, inicialmente, pelo espaço de resistência, produção e sociabilidade. Ao falarmos de grupo étnico para descrever as comunidades negras historicamente vinculadas aos quilombos, não estamos buscando pequenas Áfricas, que poderia remeter a ideia de resistência cuja contrapartida seria o retorno ao passado. O que propomos são formas de explorar a etnicidade grupal, conjugada a um sistema de organização social no qual as populações articulem "antigos costumes e formas de relacionamento social com as novas regras a que estão submetidas, de forma dinâmica, em função de uma auto-organização em termos políticos. ${ }^{.29}$

Por causa de suas dificuldades para a manutenção das terras, bem como das experiências históricas e identitárias dos afro-brasileiros,

a (re)construção de memórias do cativeiro, tem contribuído para garantir o direito de comunidades quilombolas que reivindicam o reconhecimento e a legalização de seus territórios. As pesquisas têm não somente mérito acadêmico, mas algumas auxiliam na elaboração dos laudos solicitados pelos órgãos governamentais visando ao reconhecimento e à legalização das terras ocupadas por comunidades negras. ${ }^{30}$

As formas explícitas de resistência física são as fugas, as revoltas e a formação de quilombos. Também são formas de resistência as estratégias adotadas no dia a dia pelos escravos, como: roubos, sabotagens, assassinatos, abortos e suicídios. É quase lugar-comum afirmar que "onde houve escravidão, houve resistência". Compreendendo fenômenos dos mais variados, a resistência escrava conheceu uma dimensão especial, que forma as rebeliões. Embora nem sempre

29 Arruti, "A emergência dos 'remanescentes"”, p. 26.

30 Elione Silva Guimarães, "Os arquivos locais e as comunidades negras: o Arquivo Municipal de Barbacena e o Quilombo do Paiol (Bias Fortes-MG)", Mal-Estar e Sociedade, ano 5, n. 8 (2012), p. 90. 
as rebeliões tivessem o propósito de destruir o regime escravocrata, elas representaram a principal forma de resistência coletiva, abalando a ordem política de onde elas ocorriam. ${ }^{31} \mathrm{O}$ suicídio tem sido analisado como um tipo de libertação, talvez não neste mundo, mas no outro, o do sagrado. A característica básica de resistência no sistema escravista foram as fugas. No entanto, "para um produtor direto definido como cativo, o abandono do trabalho é um desafio radical, um ataque frontal e deliberado ao direito de propriedade." ${ }^{32}$ Os quilombos pressupõem fugas para a liberdade, tanto individuais quanto coletivas. "Poucos escravos, em termos relativos, fugiram. Os que o fizeram, contudo, impuseram grandes prejuízos a seus senhores e afrontaram um sistema poderoso." ${ }^{33}$ A fuga e sua importância, como a revolta e a formação de quilombos, devem ser vistas como um ato extremo. Nas duas últimas décadas tem havido o entendimento de que a persistência dos limites entre os grupos deixa de ser colocada em termos de conteúdos culturais que encerram e definem suas diferenças. O problema da contrastividade cultural não passa mais a estar sujeito a um observador externo, que descreva as diferenças ditas objetivas, mas unicamente aos sinais diacríticos, ou seja, as diferenças que os próprios sujeitos históricos consideram significativas. As diferenças podem modificar-se, ainda que permaneça a dicotomia entre eles e nós, "marcada pelos seus critérios de pertença". ${ }^{34}$ O quilombo descolou-se dos "geografismos", mudando e indo além do parâmetro histórico e arqueológico, não consistindo mais naquela escavação onde há indícios materiais e marcas uniformes da ancianidade da ocupação. A observação que se propõe permite romper com o positivismo da definição jurídica e chama atenção para os outros instrumentos epistemológicos além do foco puramente empirista e positivista. Com base nesses novos instrumentos, que interrompem pela dialética o discurso homogeneizador, podemos reinter-

31 Keila Grinberg, Magno Fonseca Borges e Ricardo Salles, "Rebeliões escravas antes da extinção do tráfico", in Keila Grinberg e Ricardo Salles (orgs.), O Brasil Imperial: 1808-1831 (Rio de Janeiro: Civilização Brasileira, 2011), p. 237.

32 João José Reis e Eduardo Silva, "Fugas, revoltas e quilombos: os limites da negociação", in Negociação e conflito: a resistência negra no Brasil escravista (São Paulo: Companhia das Letras, 1989), p. 62.

33 Reis e Silva, "Fugas, revoltas e quilombos", pp. 62-63.

34 O’Dwyer, "Introdução", p. 15. 
pretar criticamente o conceito e afirmar que a situação de quilombo existe onde há autonomia que se configurou fora ou dentro da grande propriedade, onde a produção não passou pela mediação do senhor de escravo como mediador efetivo. A análise crítica deve perguntar como os próprios agentes sociais e históricos se definem e representam suas relações e práticas frentes aos outros grupos na interação social. Os dados de como esses povos se autodefinem são elementares na percepção da construção da identidade coletiva. A forma como os sujeitos se autorepresentam, os critérios político-organizativos que norteiam suas mobilizações e forjam a sua coesão na consubstanciação da identidade é mais importante do que a caracterização de uma agência, organização não governamental ou partido político. ${ }^{35}$

Devemos destacar que nem todos os ex-escravizados que conquistaram um pedaço de terra, seja com a formação de quilombos, seja por doação de seus ex-senhores, ocupação ou compra, conseguiram manter a propriedade conquistada. Os arquivos estão repletos de documentos comprovando que algumas doações testamentárias de proprietários agrários foram incorporadas ao longo dos anos, novamente, pelos novos senhores. No livro Terra de preto, constata-se que na maioria dos casos em que foi possível acompanhar o grupo de posseiros negros, as terras permaneceram em comum por algum tempo, sendo sua produção realizada mediante a associação dos condôminos que, além de cultivarem suas porções de terras, complementavam a renda alugando sua força de trabalho aos vizinhos mais abastados. Muitas das trajetórias acompanhadas revelam que a terra foi apoderada individualmente por alguns dos herdeiros, que a hipotecaram ou venderam o quinhão que lhes pertencia, mesmo sem que a partilha tivesse sido realizada e a terra desmembrada. ${ }^{36}$

Uma estratégia muito comum dos grandes fazendeiros da região de Barbacena e Juiz de Fora foi comprar lotes de terras em propriedades em comum, que pertenciam aos pobres ou quilombolas. Essa tática de ricos senhores mineiros alargou seus domínios sobre os quinhões de

35 Almeida, "Os quilombos", p. 68.

36 Elione Silva Guimarães, Terra de Preto: usos e ocupação da terra por escravos e libertos, Niterói: EDUF, 2009. 
pequenos camponeses negros. Muitos escravos libertos que herdaram terras perderam o domínio sobre elas ainda na primeira metade do século passado, dentro do arcabouço jurídico imprecado pelos proprietários, ou seja, na "perfeita legalidade". De fato, o domínio do Estado pelos grandes fazendeiros refletiu nas ações da Justiça. Ainda que a Justiça do final dos oitocentos se esforçou para estabelecer pequenas formas de se representar com equilíbrio, os negros e seus descendentes foram pouco ouvidos em suas demandas pelos operadores do Direito.

Mesmo não tendo contato entre si, os vários quilombos no Brasil possuem a mesma trajetória, história de luta, preservação de seus costumes e de suas terras, o que os levam à formação de uma identidade quilombola. Há ainda a integração dos membros de outras comunidades através de jogos de futebol, bailes e festas religiosas. A origem do nome Ponto Chique do Martelo deriva de dois discursos diferentes. O primeiro está relacionado à compra do terreno por parte do coronel Abel Campos que, após a construção de sua casa, organizou uma festa com convidados de toda a região. A partir deste evento, a comunidade dos Candendês se tornaria o Ponto Chique, referindo-se ao maior evento acontecido na região e com a presença de pessoas importantes. Já o segundo discurso está relacionado aos moradores das fazendas da região, pois quando iam à cidade, colocavam suas melhores vestes para chegarem ao destino bem trajados. Daí surgiu o nome "Ponto Chique", uma alusão à troca de indumentárias. Em meio às interações sociais e coletivas da comunidade, são realizadas festas de nascimento, de aniversários e de casamento. Nas terras quilombolas, a identidade é definida como uma referência, aquilo que uma pessoa ou comunidade define de si; está relacionada ao que se é (tanto individual quanto coletivamente), onde se está (comunidade/ território) e o que se quer (projeto de futuro). Neste sentido, as comunidades são compreendidas como rurais e urbanas, que se autodefinem pela ancestralidade africana, pelo alto grau de parentesco existente no território, pois os membros da comunidade trocam convites para serem padrinhos de nascimento e casamento, reforçando as relações sociais, e na expressão de identidade coletiva mantida através dos tempos. Assim, compreender-se como pertencente a um grupo e a um território é o que evidencia sua identidade. 


\section{Justiça e direito}

Em meados do século XIX, alguns senhores na iminência da morte legaram verbas testamentárias para pessoas próximas. Alguns escravos foram beneficiados com as doações post-mortem. No entanto, resta a dúvida se os escravos conseguiram esses legados, pois Barbacena, além de região agrária, encontrava-se sob mudanças jurídicas no que concerne ao fim das sesmarias e a nova legislação decorrente da Lei de Terras, que, promulgada em 18 de setembro de 1850, foi a primeira iniciativa no sentido de organizar a propriedade privada no Brasil. O governo determinaria o prazo para a "legalização" das terras, podendo as províncias prorrogá-lo. Ela veio regulamentar a posse de terras, em decorrência das transformações sociais e econômicas pelas quais passava o país, estabelecendo a compra como a única forma de acesso à terra e abolindo, em definitivo, o regime de sesmarias (posse e terras devolutas). A Lei teve origem em um projeto de lei apresentado ao Conselho de Estado do Império, em 1843, por Bernardo Pereira de Vasconcelos, político, jornalista, juiz de fora e jurista mineiro. ${ }^{37}$ De fato, com a implantação da Lei de Terras, houve um aumento de seu valor venal, dificultando o acesso dos imigrantes recém-chegados ao Brasil e dos ex-escravos. ${ }^{38}$ Neste contexto, as relações escravistas passaram por novos ordenamentos e readaptações, aproveitando-se das transformações advindas com as novas leis prospectivas de visões de liberdade. ${ }^{39}$

Diversos trabalhos historiográficos discutem as diferentes estratégias adotadas pelos escravos, quase sempre marcadas por habilidades, informações, comportamentos e sentimentos que contribuíram para que alcançassem a liberdade legalmente. As alforrias resultaram de negociações, muitas vezes marcadas por investimentos dos escravos, não apenas individuais, mas também coletivos. Por isso, a alforria nunca é uma aventura solitária. Ela "resulta de todo um tecido de solidariedades

37 Onete da Silva Podeleski, "Lei de Terras de 1850", Revista Santa Catarina em História, v.1, n. 2 (2009), pp. 47-58.

38 Márcia M. Menendes Motta, Nas fronteiras do poder: conflitos e direito a terra no Brasil do século XIX, Rio de Janeiro: Vício de Leitura, 1998.

39 Sidney Chalhoub, Visões da liberdade: uma história das últimas décadas da escravidão na Corte, São Paulo: Companhia das Letras, 2011. 
múltiplas e entrelaçadas, de mil confabulações, processos de compensações, promessas feitas e mantidas, preceitos, até mesmo conveniência, reflexos e imagens mentais. ${ }^{\text {40 }}$ Quando pensamos no processo de alforrias na pia batismal, temos que levar em conta que elas eram o resultado de negociações estabelecidas entre senhores e os interessados em libertar os infantes.

Os cativos laçaram mão de inúmeras formas de resistência ao sistema escravista para conquistar a liberdade, por exemplo, rebelando-se, mentindo e fugindo para quilombos. No entanto, esses sujeitos encontraram formas mais "brandas", muitas vezes "sutis", para conseguir sua liberdade, seja boicotando o trabalho, provocando intrigas, negociando ou submetendo-se. A partir dessas estratégias, bem aplicadas e, melhor ainda, bem calculadas, poderiam fazer com que seu senhor the concedesse a liberdade. Kátia Mattoso afirma que a fidelidade, a obediência e a humildade eram as três qualidades básicas que poderiam levar um escravo a alcançar legalmente a sua liberdade, sem precisar se rebelar e fugir para os quilombos. Dessa forma, o escravo doméstico era o mais privilegiado. Os escravos crioulos ou mestiços também levaram vantagem na conquista da liberdade por serem, em geral, educados pelos seus senhores, por terem tido a oportunidade de aprender um ofício e porque, desde cedo, forjaram laços afetivos com os senhores. ${ }^{41}$

Com o auxílio da mão de obra escrava, a posse de terras mais férteis garantia a sustentação, pelos potentados locais, do poder de mando e a afirmação de seu prestígio. A região de Padre Brito, em Barbacena, e a de Ibertioga, situada a $16 \mathrm{~km}$ da comunidade dos Candendês, foram espaços de uso intensivo de produção escrava. A região do Ponto Chique é apenas um exemplo da vitalidade conjugada com a resistência de pessoas que ajudaram no desenvolvimento local. A mão de obra dos escravos usada compulsoriamente nas fazendas destinava-se ao cuidado do gado vacum, de cavalos, de bestas, porcos e ovelhas. Dentro das fazendas a produção doméstica utilizava a disponibilidade do algodão e lã para fios e panos. O gado e os porcos eram levados para o Rio de Janeiro pelos tropeiros, constituídos de homens livres e escravos. Da capital eram tra-

40 Kátia M. de Q. Mattoso, Ser escravo no Brasil, São Paulo: Brasiliense, 1990, p. 194.

41 Mattoso, Ser escravo, pp. 170-172. 
zidos linhas, fitas, tecidos, sapatos, bombachas, roupas, vinagre, sal e outros produtos para o consumo local. Essa acumulação de capitais possibilitava o acesso dos fazendeiros locais a cargos de oficiais de milícias e à ocupação de órgãos da administração colonial, fortalecendo assim os seus poderes que desdobravam em mais conquistas de terras e a necessidade de mais mão de obra, criando um ciclo dinâmico na economia da região a tal ponto que a crise mineratória fosse superada de forma mais harmoniosa. Em consonância com o desenvolvimento histórico do Termo de Barbacena, mais da metade dos moradores, perto de 52\% da parcela que se tem notícia, trabalhava na agricultura e na pecuária. Nesse mundo rural, fortemente vinculado ao mercado de abastecimento da Corte, chama a atenção a presença de ocupações ligadas ao universo tropeiro e pastoril. Em Barbacena, além de agricultores, criadores e tropeiros, viviam campeiros, boiadeiros, camaradas de tropas, arrieiros, carreiros, fazedores de chicote, seleiros, ferreiros, picadores e peareiros. A performance dessas atividades, sem dúvida, era fundamental para garantir os progressos dos negócios da região. ${ }^{42}$

Não obstante a elite política ter tido uma relação íntima com os representantes da classe economicamente dominante, não se trata de enxergar as classes enquanto reflexo das relações econômicas, pois elas são construídas historicamente, e quando se constroem, edificam o Estado como elemento mediador e organizador. A elite política representa os intelectuais orgânicos de um grupo social, responsáveis por inserir-se na vida prática, como construtora e persuasora permanente visando a conquista do consenso e da hegemonia, necessários à expansão da própria classe. ${ }^{43}$ A política dos governadores se assenhorou do discurso desta elite para se legitimar frente ao Estado, criando uma ilusão de consenso na sociedade, pois apenas os coronéis revessavam-se como mediadores estatais. Trabalhadores urbanos e rurais, descendentes de escravos e ex-escravos ficaram como espectadores da arena política na Primeira República. A elite política é capaz de "naturalizar" a dominação, fazen-

42 Edna Maria Resende, "Ecos do liberalismo: ideários e vivências das elites regionais no processo de construção do Estado imperial, Barbacena (1831-1840)" (Tese de Doutorado, Universidade Federal de Minas Gerais, 2008), p. 124.

43 Antônio Gramsci, Os intelectuais e a organização da cultura, tradução de Carlos Nelson Coutinho, Rio de Janeiro: Civilização Brasileira, 1982. 
do com que frações de classes incorporem as representações da classe dominante, buscando o consenso ao projeto de sociedade proposto por ela. Por deter um poder simbólico, a elite alcança uma dominação legítima e consentida de poder. A classe proprietária lança mão do poder simbólico e da distinção para confirmar ou transformar a visão de mundo e ação sobre o mundo. ${ }^{44}$

O Termo de Barbacena era um amplo e complexo entreposto mercantil-escravista, cujos senhores mantinham um controle feroz sobre a escravaria e, ao mesmo tempo, tinham o cuidado para dominar seus complexos de fazendas e "negociar" com a escravaria. ${ }^{45}$ Em 1887, foi feito o testamento de Francisco de Assis Pacheco Penna, juntamente com o inventário, mas só no ano de 1890 localizamos suas contas da testamentaria, na qual se encontra a declaração do coronel Rufino José Ferreira, datada de 1889, registrando que após o falecimento de Pacheco Penna, foram declarados livres todos os seus escravos e que foram escolhidos para eles 100 alqueires na Fazenda do Repouso, para morarem e trabalharem de acordo com a "quarta verba" do testamento. ${ }^{46}$

O coronel Rufino José Ferreira era pessoa de alto cabedal político e econômico no Termo de Barbacena. Além do poder local, ele possuía várias fazendas na região de Torres, hoje distrito de Barbacena, e amigos na localidade de Ilhéus, atual Padre Brito, região do Quilombo dos Candendês. Ele possuía um montante líquido, quando morreu em 10 de junho de 1919, no valor de 207:844\$000 (duzentos e sete contos, oitocentos e quarenta e quatro mil réis). ${ }^{47}$ No referido inventário, além de casas de vizinhos e agregados, localizamos terras de alqueires nas divisas da Fazenda do Repouso, da Fazenda de Carranca com o "Galego e

44 Pierre Bourdieu, A economia das trocas simbólicas, tradução de Sérgio Miceli, Silvia de Almeida Prado, Sônia Miceli e Wilson Campos Viera, São Paulo: Perspectiva, 2003.

45 Monica Ribeiro de Oliveira, "Negócios de família: mercado, terra e poder na formação da cafeicultura mineira" (Tese de Doutorado, Universidade Federal Fluminense, 1999).

46 Contas de Testamentaria de Francisco de Assis Pacheco Penna, 1890, Arquivo Histórico Municipal Professor Altair Savassi (AHMPAS), cx. 15, ord. 8, 1SVC, fl. 23.

47 Inventário de Rufino José Ferreira, 10/06/1919, Arquivo Histórico Municipal Professor Altair Savassi (AHMPAS), cx. 139, ord. 6, 1SVC, fls. 37-38. 
terras dos ex-escravos do finado Francisco de Assis Pacheco Penna". ${ }^{48}$ Essas terras circundam o território dos Candendês.

$\mathrm{Na}$ análise do inventário de Manoel Moreira Campos, confirma-se que ele era senhor de grande poder político e econômico no Termo de Barbacena, proprietário de várias fazendas em Ilhéus e Santana de Barroso, estendendo relações de parentesco para várias regiões. Seu filho, conhecido como coronel Abel Moreira Campos, herdou parte da riqueza do pai, comprando e herdando terras na região de Ilhéus e Ibertioga. Ilhéus era uma localidade próxima à região de Santana de Barroso, onde se encontrava a fazenda Boa Esperança e Caxambu, que entrelaçava dinamicamente a rede de comunidades rurais de ex-escravos na região de Barbacena.

Maria Olinda de Campos era neta de Rufino José Ferreira, casada com José Nicodemos de Campos. Este último descende de Manoel Moreira Campos. A demonstração dessas relações é para circunscrever duas regiões, a de São Sebastião dos Torres à vila de Ilhéus. As relações consanguíneas das elites interconectam duas "terras de pretos". Abel Moreira Campos possuía amplas terras na região de Ilhéus, fazendo divisas com a comunidade denominada de "Crioulos", espaço reorganizado com base nas experiências tecidas após a abolição. Essa comunidade se desenvolveu mantendo relações como os brancos e grandes senhores da circunvizinhança. Estes, mais fortes econômica e militarmente, forjaram um contexto no qual os ex-escravos tiveram que adotar medidas de paciência para aceitar o que não podia ser evitado, garantindo a sobrevivência do grupo. ${ }^{49}$ Atravessando as dificuldades inerentes ao período do cativeiro, os ex-escravos se consolidaram na região de Ilhéus. Essa comunidade rural de "Crioulos", também conhecida como "Sítio dos Candendês", tem seu nome ligado à família de Antônio Lourenço, o Candendê, que "falava meio embolado", usava algumas palavras do idioma africano e "gostava de benzer" utilizando um rosário no pescoço.

48 Contas de Testamentaria de Francisco de Assis Pacheco Penna, 1890, op. cit., fls 24-24.

49 Eugene D. Genovese, A Terra Prometida: o mundo que os escravos criaram, tradução de Maria Inês Rolim e Donaldison Magalhães Garshagen, Rio de Janeiro: Paz e Terra, Brasília: CNPq, 1988, p. 392. 
Na formação do Quilombo dos Candendês o discurso que nos parece mais confiável e que se ajusta a nossa investigação é o de que as terras onde moram os Candendês foram espaços societários formados por libertos antes da abolição, consolidado com a presença dos escravos após 13 de maio de 1888. Mesmo que essa terra tenha sido doada, não a descaracteriza como sociedade quilombola. Embora a Carta Ultramarina determinasse que quilombo era uma habitação de negros fugidos resistentes à escravidão, a perspectiva historiográfica, antropológica e jurídica hoje configura como quilombos todos os espaços construídos por formas e processos de ocupações, constituindo desde as heranças, passando por doações, trocas de serviços prestados ao Estado ou a compra. Portanto, o conceito de quilombo é redimensionado, indo além da ideia de agrupamento formado por fugas e resistências violentas.

Os bantos da África meridional estão representados por povos que falam entre setecentas e duas mil línguas e dialetos aparentados, logo abaixo dos limites sudaneses, compreendendo as terras que vão do Atlântico ao Índico até o Cabo da Boa Esperança, no sul do continente. O termo "banto" foi criado em 1862 pelo filólogo alemão Willelm Bleek e significa "o povo", não existindo propriamente uma unidade banto na África. ${ }^{50} \mathrm{Em}$ Palmares falava-se umbundo e kimbundo, misturados com a Língua Geral. As próprias palavras Zumbi e Ganga Zumba são um banto, conjunto de línguas nigero-congolês oriental. Aproximadamente $90 \%$ dos quilombos mineiros dos anos 1700 tiveram os nomes e quilombolas bantos. Por sua vez, predominava nas comunidades de afrodescendentes os dialetos bantos. A unidade linguística dos povos desta região africana, quando transportados para o Brasil e Minas Geras, não demoraram a expressar o elo cultural comum. Dessa forma, todas as trezentas línguas banto possuem um parentesco muito próximo, o que enseja um "barco semântico" e um "mar ontológico" via palavra. ${ }^{51}$ A maioria dos escravos que vieram para a região de Barbacena era da África centro-ocidental. O Quilombo dos Candendês, cuja escrita grafava Kandendês, foi for-

50 Reginaldo Prandi, "De africano a afro-brasileiro: etnia, identidade, religião", Revista da USP, n. 46 (2000), pp. 52-65.

51 Robert Slenes, “'Malungu, ngoma vem!': África coberta e descoberta do Brasil”, Revista da USP, n. 12 (1991-1992), p. 49. 
mada por ex-escravos congo-angolenses que se refugiaram na região da Kandonga (Candonga), também conhecida como Ponto Chique do Martelo, subordinada à antiga Ilhéus. Por isso, Kandendê se origina de algum descendente do grupo étnico dos Kimbundos ou dos Umbundos, do grupo linguístico banto.

Quando falo de quilombo, refiro-me a território quilombola, forjado na luta pelo espaço vivido e pelo domínio do tempo da memória coletiva, para fazer justiça com direito. O conceito de territorialidade, definido em termos antropológicos, como o esforço coletivo de um determinado grupo social para usar, ocupar, "controlar e se identificar com uma parcela específica de seu ambiente biofísico, convertendo-o assim em seu território", o território seria "um produto histórico de processos sociais e políticos". 52

Já consolidado enquanto território de quilombolas na virada do século XIX, o sítio dos Candendês tem o reconhecimento pelo Estado ao delimitar o espaço e suas fronteiras em 1911:

Art. $4^{\circ}$. Ficam suprimidos os seguintes distritos:

III - De Ilhéus, no município de Barbacena, anexado o respectivo território aos distritos da cidade de Barbacena e de Ibertioga, conforme as divisas estabelecidas nesta lei.

Art. $9^{\circ}$. As divisas dos atuais municípios e distritos mencionados no quadro anexo são as estabelecidas na legislação em vigor com as seguintes alterações:

LXII - As divisas entre o distrito de Ibertioga e o da cidade de Barbacena, no mesmo município, são as seguintes: - do ribeirão da Conquista pelo valo acima até a porteira da Cruz no alto da fazenda das Três Pontas - daqui seguindo a estrada que vai para o povoado Ilhéus até a porteira que entra para o sitio dos Candendês ou Crioulos, daí seguindo o valo que margeia estrada de comércio com direção à estação de Ilhéus até a porteira que entra para o pasto da Cruz das Almas, daqui seguindo o valo a esquerda

52 Paul E. Little, "Territórios sociais e povos tradicionais no Brasil: por uma antropologia da territorialidade", Série Antropologia, n. 322 (2002), p. 3. 
até a porteira do Capim da fazenda do Gouvêa, por este abaixo até o Brejo, por este até o córrego do Corvo, por este abaixo até o córrego que vem do pasto da Rainha, por este até o valo do pasto do Lopes, por este acima até a porteira do mesmo pasto, por este, à direita, até a porteira do Capão dos Pimentas, seguindo o valo até o córrego das Bicas, desde à esquerda pelos valos até a porteira dos pasto do Silvério e por este valo até o rio Elvas. Nestas divisas fica o território da estação de Ilhéus, da Estrada de Ferro Oeste de Minas, pertencendo ao distrito de Barbacena - e os terrenos compreendidos por esta divisa são resultantes do distrito de Ilhéus, suprimido por esta lei. (grifos nossos) ${ }^{53}$

O documento supracitado indica os territórios adquiridos por libertos, ex-escravos e descendentes. "Terras de pretos", "comunidades de Crioulos" ou "Sítio dos Candendês" demarcam espaços de vida e conquistas dos negros, ambientes onde se forjaram a identidade negra e as formas de resistência no cotidiano. Um outro documento de divisão de terras, cujo adquirente era Joaquim Rodrigues Pereira Primo, confirma a existência do território dos Candendês, dividindo espaço com o Capão das Mulatas, ou seja, uma localidade comunitária de mulheres afrodescendentes surgidas no tempo da escravidão. De acordo com o documento, o terreno foi descrito dividindo as terras:

dos Candendês, pelas divisas de dona Balbina Vargas até as de Honório de Paula Campos, por estas até as de José Rodrigues Campos, segue até a barra do lagrimal, por ele acima até um copim em um côvado, deste direito a outro côvado na beira da estrada em rumo a outro perto de um pau de Ipê e deste ao lado direito a um pau de pinho, deste ao lado direito a um cavado na beira do córrego da Chapada, por este abaixo até a divisa de Nestor Rodrigues Pereira, por estas até as divisas de Manoel Moreira Campos,

53 Minas Gerais, Lei n. 556/1911 de 30 de agosto de 1911, <https://www.almg.gov.br/consulte/ legislacao/completa/completa-nova-min.html?tipo=LEI\&num=556\&ano=1911>, acessado em 15/10/2019. Grifos nossos. 
Francisco Rodrigues Pereira até o começo que desce do "Capão das Mulatas", sobre este até onde começou. (grifos nossos) $)^{54}$

Tanto o texto da Assembleia Legislativa do Estado de Minas Gerais quanto o estrato da escritura de divisão de terras configuram a existência de comunidades comuns de ex-cativos, confirmando redes de famílias ex-escravas circundadas pelos fazendeiros e elites políticas locais. Como documentos oficiais, estes revelam as terras como pertencentes aos Candendês, na lei e no fato.

Essas conjecturas dialogam com aquilo que disse Márcia Motta. De fato, essa autora afirmou que os fazendeiros haviam erigido uma sociedade na qual os limites das terras estavam intimamente relacionados e interconectados à criação de uma poderosa rede de relações pessoais. Um determinado fazendeiro, pertencente à elite local, por mais rico e influente que fosse, para defender-se de um ocupante de terras precisava reafirmar a sua condição de senhorial e detentor de posse no momento da escolha das testemunhas em um eventual processo judicial movido por ele contra outras pessoas ou movido contra ele em demandas relacionadas às questões relativas à posse da terra. Igualmente, ao registrar ou vender suas terras com os limites territoriais que alegava ser dono, o fazendeiro precisava contar também com suas redes de relações pessoais para rearranjar ou mesmo recriar, nos cartórios locais, tal como foi feito no cartório de Padre Brito, antiga Ilhéus, a extensão alegada e seu respectivo preço ou dimensão. Ao comercializar uma determinada parte de suas terras, o fazendeiro não somente a transferia, mas também reorientava a transferência de seu poder sobre os homens e mulheres que ali habitavam e confrontavam com sua propriedade. ${ }^{55} \mathrm{O}$ seu poder simbólico estava prefigurado pela posse e transferência da terra. Isso não mudou com a promulgação da Lei de Terras em 18 de setembro de 1850, pois de acordo com os novos dispositivos estabelecidos pelo ordenamento jurídico, essas relações talvez tenham até sido recrudescidas num processo inverso ao civilizatório.

54 Extrato de escritura de divisão de terras, 1920, Arquivo Histórico Municipal Professor Altair Savassi (AHMPAS), cx. 178, ord. 41, 2SVC, fls. 1-1v. Grifos nossos.

55 Motta, Nas fronteiras do poder, p. 228. 
Os cativos nascidos no Brasil possuíam o aprendizado de uma política de negociação desenvolvida no campo dos costumes, do direito e do poder dos senhores. Se a possibilidade dessa política representou para os senhores uma forma de produzir fidelidades e potencializar o nível de sua autoridade entre os cativos, para os escravos ela buscou a miragem da alforria. A frustação das expectativas pelos senhores dependia de um cálculo sobre os riscos de insubordinação. Do ponto de vista senhorial, a manobra deveria estar muito bem regulada. ${ }^{56} \mathrm{O}$ proprietário Abel Carlos Moreira Campos, cuja fazenda localizava-se na Região de Ilhéus, hoje Padre Brito, era familiar de Honório de Paula Campos e cunhado de José Luiz de Campos, proprietário da Fazenda do Martelo, todos importantes representantes das elites locais. Eles eram confrontantes da Fazenda da Candonga e também com o Sítio dos Candendês, o que sugere que estavam próximos e reconstruíram relações cotidianas interpenetradas. Os moradores e vizinhos da Fazenda da Candonga reconheciam as terras das comunidades afrodescendentes.

\section{Conclusão}

A formação da identidade dos membros da comunidade quilombola se faz tanto pelo viés da semelhança quanto do contraste. O contraste se faz em relação aos outros trabalhadores rurais e proprietários de terras da região que não são negros, o que nos permite dizer que a identidade é construída a partir da necessidade de lutar pelas suas terras, mas também pela diferença de trato com as comunidades descendentes de italianos na região, emitido tanto pelo poder político local como por parte dos demais setores da sociedade. Em pesquisa de campo na comunidade entre 2013 a 2015, percebi a diferença dispensada aos quilombolas pelas autoridades locais. Enquanto as terras dos fazendeiros, ricos e brancos, recebem todas as formas de incentivo, a terra dos Candendês fica marginalizada pelo poder público. A comprovação está estampada no próprio Plano Inventário do Município de Barbacena, que associa o povoamento do Ponto Chique do Martelo à figura de Antônio Louren-

56 Hebe Maria Mattos, "Laços de família e direito no final da escravidão", in Luiz Felipe de Alencastro (org.), História da vida privada no Brasil: Império: a corte e a modernidade nacional (São Paulo: Companhia das Letras, 1997), vol. 2, pp. 353-354. 
ço, o Candendê, e a de Padre Brito, distrito limítrofe ao Ponto Chique, à figura do Coronel Abel. De acordo com o Plano Inventário, os imóveis históricos, que poderiam ser tombados na Comunidade dos Candendês, estão em ruínas devido ao descaso das autoridades do município, estado e da União. Portanto, é com base na percepção deste contraste que os moradores da Comunidade dos Candendês identificam-se por semelhança e como iguais entre si, construindo a identidade local, e, por sua vez, é a partir desta situação de contraste que os Candendês aprenderam a se perceber como diferentes dos outros e iguais entre os seus. Assim, dividindo o mesmo espaço físico e a mesma história de vida, buscam o seu reconhecimento como cidadãos brasileiros e quilombolas. $\mathrm{O}$ autorreconhecimento sempre representou um objetivo a ser alcançado pelo movimento negro nacional, procurando incutir um sentimento de identificação entre os membros e simpatizantes. ${ }^{57}$

Neste texto, busquei reconstituir uma história interrompida que foi silenciada durante algum tempo, mas que é vivenciada cotidianamente pela comunidade quilombola dos Candendês. Os silêncios dos vencidos da história são reveladores dos mecanismos de manipulação da memória coletiva. Procurei mostrar que o Termo de Barbacena, dentro da Comarca do Rio das Mortes, era um complexo entreposto mercantil e escravista no século XIX, no qual os grandes senhores e as elites locais conservaram um rigoroso controle sobre os escravos. No entanto, os imponentes escravagistas tiveram o cuidado de negociar algumas formas de convivência no sistema de dominação para que a onda rebelde não se espalhasse.

A região de Barbacena caracterizou-se pela presença de pequenos plantéis de escravos adquiridos no tráfico interprovincial, já que não houve na região das vertentes grandes plantations, e as zonas mineradoras de maior vulto estavam relativamente distantes. A extração de ouro configurou-se a partir de pequenos faiscadores, o que exigia pouca mão de obra. A dinâmica da produção possibilitou a aproximação entre senhores e escravos, o que forçou estratégias dos dois lados para que os conflitos latentes não se tornassem manifestos nas ações ordinárias. As relações

57 Jurandir de Souza, "Espaço e territorialidade afro-descendente em Curitiba", in Histon Costa e Paulo Vinícius Baptista da Silva (orgs.), Notas de história e cultura afro-brasileira (Ponta Grossa: Editora da UEPG, 2011), p. 131. 
de submissão ocultaram as condições desfavoráveis no jogo do poder para se manter a ordem, pois o monopólio da violência estava assegurado para uma classe e não apenas pelo Estado. Os potentados locais, com a assistência da mão de obra escrava, garantiram a sua sustentação e o poder de mando. Além disso, a classe proprietária lançou mão do poder simbólico e da distinção para confirmar a sua visão e ação de mundo. No século XIX e início do XX, o ordenamento jurídico veio respaldar os interesses políticos das elites e o monopólio da violência foi usado principalmente contra os povos subalternos. Alguns senhores tomavam os cativos com o objetivo de fazer justiça com as próprias mãos, pois achavam que a violência estatal não era suficiente para punir os escravos de acordo com a sua noção de justiça. Por isso, a fuga e a revolta escrava, bem como a formação de quilombos, devem ser vistas, também, como um ato de busca de justiça subalterna.

Em Minas Gerais, confirmou-se que os quilombos não eram territórios isolados, mas espaços de relações econômicas, culturais e familiais. $\mathrm{O}$ desejo de ser quilombola forçou muitos senhores a amenizar as brutalidades com os escravos em determinados contextos sociais e políticos. Os quilombos expressaram a luta contra a intransigência de senhores que desrespeitavam certos ganhos, que os escravos começaram a considerar como direitos, conquistados no dia a dia. Muitos escravos libertos que herdaram terras, ou as conquistaram por ocupação ou compra, perderam o domínio sobre elas dentro do arcabouço jurídico configurado pelas elites proprietárias, fazendo com que essas posses fossem, ao longo dos anos, novamente incorporadas pelos novos senhores, como foram as áreas ao redor da Comunidade Quilombola dos Candendês.

Almejei, com este texto, a possibilidade de reconhecimento histórico e antropológico da Comunidade Quilombola dos Candendês, pois a região do Ponto Chique do Martelo é apenas um exemplo da vitalidade, conjugada com a resistência, de pessoas que ajudaram no desenvolvimento regional de Barbacena. Demonstrei que o Sítio dos Candendês, formado na virada do século XIX, teve o reconhecimento pelo Estado, ao delimitar o espaço e suas áreas de fronteiras em 1911 e mostrei a vida assentada nos inventários pautando as terras de ex-escravos de grandes fazendeiros locais. Os textos da Assembleia e os estratos de escritura de 
divisão de terras confirmaram a existência de comunidades comuns de ex-cativos, ou seja, tanto na lei como no fato, a terra teve e tem um fim social e produtivo para os quilombolas.

Os residentes dessas terras de pretos sempre retiraram do solo os seus produtos de subsistência, o que não se reduz à alimentação, pois é no campo e nas florestas que os habitantes põem à prova as suas manifestações culturais e sociais para a preservação de seus costumes, crenças e religiões. A presença dos mais antigos e dos tradicionais na comunidade, detentores do saber acumulado das gerações passadas, fortalece a vinculação entre identidade e ancestralidade nas terras laboradas. Por tudo isso, e amparado na documentação analisada, concluí que os quilombolas dos Candendês são os legítimos herdeiros das terras da região de Barbacena. Essa comunidade deve ser reconhecida para respaldar esse universo de bens materiais e simbólicos como experiências societárias legítimas.

Recebido em 21/2/2018 e aprovado em 09/05/2019 


\title{
Resumo
}

Este artigo falará sobre os quilombolas dos Candendês, comunidade situada na localidade do Ponto Chique do Martelo, distrito de Barbacena, Minas Gerais. Busca-se reconstituir aspectos da história silenciada dos Candendês, pois os silêncios dos vencidos são reveladores dos mecanismos de manipulação da memória. Na formação de quilombos estava a luta contra a intransigência de senhores que desrespeitavam os ganhos que os escravos começaram a considerar como direitos. Por conseguinte, a região de Barbacena se caracterizou pela presença de pequenos plantéis de escravos adquiridos no tráfico interprovincial. Mostra-se que o território dos Candendês teve o reconhecimento pelo Estado ao delimitar as áreas de fronteiras em 1911. E, amparando-se na documentação e nas leis, pode-se afirmar que os Candendês são os legítimos herdeiros daquelas terras da região mineira.

Palavras-chave: quilombo - Candendês - direito - escravos - identidade.

\begin{abstract}
This article discusses about the Quilombolas dos Candendês, a community located at Ponto Chique do Martelo, Barbacena district, Minas Gerais, Brazil. It tries to reconstitute aspects of the silenced history of the Candendês, for the silence of the conquered reveals the mechanisms of manipulation of memory. The struggle against the intransigence of slaveholders who disrespected the gains considered as rights by the slaves was in the formation of quilombos. Therefore, the region of Barbacena was characterized by the presence of small slave farms acquired in the interprovincial trade. The article shows that the territory of the Candendês was recognized by the State by delimiting the frontier areas in 1911. Based on the documentation and the laws, it is possible to affirm that the Candendês are the legitimate heirs of those lands in the region of Minas Gerais.
\end{abstract}

Keywords: quilombo - Candendês - law - slaves - identity. 